Www.jmscr.igmpublication.org

Index Copernicus Value: 79.54

ISSN (e)-2347-176x ISSN (p) 2455-0450

crossrefDOI: https://dx.doi.org/10.18535/jmscr/v7i2.108

\title{
A study on Demographic characteristics and Clinical Spectrum of Complications of CSOM
}

\author{
Authors \\ Dr A.S Aruna Kumari ${ }^{1}$, Dr Novshaba ${ }^{2}$ \\ ${ }^{1}$ Associate Professor, Govt. ENT Hospital, Koti, Osmania Medical College, Hyderabad \\ ${ }^{2}$ Senior Resident, Govt. ENT Hospital, Koti, Osmania Medical College, Hyderabad
}

\section{Introduction}

Chronic otitis media is the inflammatory disorder of middle ear cleft which is characterised by the permanent defect in pars tensa or pars flaccida. ${ }^{1}$ Highest incidence of chronic otitis media is seen in developing countries. ${ }^{2}$ Chronic Otitis Media can progress to serious complications if left unattended. Complications are grouped into Intratemporal and Intracranial complications. ${ }^{3}$ The factors responsible for the progression of disease to complications include virulence of organism, resistance offered by patient, inappropriate use of antibiotic, and antibiotic resistance. ${ }^{2}$ Even though there has been decrease in the incidence of complications due to advent of vaccinations and antibiotics these complications are life threatening and need early recognition and prompt management. ${ }^{4}$ The most common routeof spread of complications is bone erosion by the disease process in squamosal $\mathrm{COM}$ and via vascular channels in mucosal $\mathrm{COM}^{5}$

\section{Aim \& Objectives}

- To describe the demographic characteristics and clinical spectrum of Complications of COM
- To identify the role of different management strategies in preventing and managing the complications

\section{Inclusion criteria}

- All age group of COM mucosal and squamosal patients presenting with intra and intra temporal complications

\section{Exclusion criteria}

- Revision cases

\section{Materials \& Methods}

Study Design: Retrospective

Study Duration: 2 Years

Sample Size: 100

Study Area: Govt. ENT hospital, Koti, Telangana

Patients of COM were subjected to detailed history taking and ENT examination. Radiological investigations were ordered depending upon the pathology. Neurosurgeons and Neurophyscians opinion was sought as and when required. Consent for the treatment was taken. Medical and surgical management was done based on pathology. Referral to neurosurgeon was done for neurosurgical intervention. 


\section{Results}

1930 patients of COM presented to tertiary care hospital of which 100 patients had complications.
Of 100 complicated COM cases 44 cases were Active Mucosal and 56 cases were Active Squamosal.

Table 1: Distribution of study population according to Socio - Demographic characteristics

\begin{tabular}{|l|c|c|c|}
\hline Age group & $\begin{array}{c}\text { Active } \\
\text { mucosal } \\
\text { Total : 44 })\end{array}$ & $\begin{array}{c}\text { Active } \\
\text { squamosal } \\
(\text { Total : 56 })\end{array}$ & Total ( 100 ) \\
\hline $0-10 \mathrm{yrs}$ & $7(16 \%)$ & $3(5.4 \%)$ & $10(10 \%)$ \\
\hline $11-30 \mathrm{yrs}$ & $17(38.6 \%)$ & $13(23.2 \%)$ & $30(30 \%)$ \\
\hline $31-60 \mathrm{yrs}$ & $16(36.3 \%)$ & $40(71.4 \%)$ & $56(56 \%)$ \\
\hline$>60 \mathrm{yrs}$ & $4(9.1 \%)$ & - & $4(4 \%)$ \\
\hline Gender & $\begin{array}{c}\text { Active } \\
\text { mucosal } \\
(\text { Total : 44 })\end{array}$ & $\begin{array}{c}\text { Active } \\
\text { squamosal } \\
(\text { Total : 56 })\end{array}$ & Total ( 100 ) \\
\hline Male & $26(59 \%)$ & $34(60.7 \%)$ & $60(60 \%)$ \\
\hline Female & $18(41 \%)$ & $22(39.3 \%)$ & $40(40 \%)$ \\
\hline Locality & $\begin{array}{c}\text { Active } \\
\text { mucosal } \\
(\text { Total : 44 })\end{array}$ & $\begin{array}{c}\text { Active } \\
\text { squamosal } \\
(\text { Total : 56 })\end{array}$ & Total ( 100 ) \\
\hline Urban & $11(25 \%)$ & $15(26.8 \%)$ & $26(26 \%)$ \\
\hline Rural & $33(75 \%)$ & $41(73.2 \%)$ & $74(74 \%)$ \\
\hline Socio economic status & $\begin{array}{c}\text { Active } \\
\text { mucosal }\end{array}$ & $\begin{array}{c}\text { Active } \\
\text { squamosal }\end{array}$ & Total ( 100 ) \\
$($ Total : 44 $)$ & $($ Total : 56 $)$ & \\
\hline Upper & - & $2(3.6 \%)$ & $2(2 \%)$ \\
\hline Middle & $12(27.3 \%)$ & $8(14.3 \%)$ & $20(20 \%)$ \\
\hline Lower & $32(72.7 \%)$ & $46(82.1 \%)$ & $78(78 \%)$ \\
\hline
\end{tabular}

In the present study the maximum incidence of Complicated COM cases were seen in $31-60$ yrs of age group ( $56 \%$ ). In Active Mucosal COM the maximum incidence was seen in $11-30 \mathrm{yrs}$ of age group (38.6\%) whereas in Active Squamosal COM the maximum incidence was seen in $31-60$ yrs of age group (71.4\%). The male to female ratio in Complicated $\mathrm{COM}$ cases were $1.5: 1$. In Active Mucosal COM the male to female ratio was $1.4: 1$ whereas in Active Squamosal COM it was 1.5:1. The maximum incidence of Complicated COM cases was seen in Rural population (74\%), Active Mucosal COM cases accounting to $75 \%$ and Active Squamosal COM accounting to $73.2 \%$. Complicated $\mathrm{COM}$ cases highest incidence was noted in individuals belonging to low socio economic status (78\%) in the present study.

Table 2: Distribution of study population according toClinical Profile

\begin{tabular}{|l|c|c|c|}
\hline Side of ear & $\begin{array}{c}\text { Active } \\
\text { mucosal } \\
\text { Total : 44 })\end{array}$ & $\begin{array}{c}\text { Active } \\
\text { squamosal } \\
\text { ( Total : 56) }\end{array}$ & Total( 100 ) \\
\hline Right & $22(50 \%)$ & $22(39.3 \%)$ & $44(44 \%)$ \\
\hline Left & $22(50 \%)$ & $34(60.7 \%)$ & $56(56 \%)$ \\
\hline Presenting complaint & $\begin{array}{c}\text { Active } \\
\text { mucosal } \\
\text { Total : 44) }\end{array}$ & $\begin{array}{c}\text { Active } \\
\text { squamosal } \\
\text { ( Total : 56) }\end{array}$ & Total( 100 ) \\
\hline Otorrhea & $44(100 \%)$ & $56(100 \%)$ & $100(100 \%)$ \\
\hline Decreased hearing & $44(100 \%)$ & $44(78.6 \%)$ & $88(88 \%)$ \\
\hline Otalgia & $34(77.3 \%)$ & $42(75 \%)$ & $76(76 \%)$ \\
\hline Dizziness & $1(2.3 \%)$ & $4(7.1 \%)$ & 5 \\
\hline Facial weakness & $10(22.7 \%)$ & $12(21.4 \%)$ & $22(22 \%)$ \\
\hline Swelling behind the ear & $18(40.9 \%)$ & $13(23.2 \%)$ & $31(31 \%)$ \\
\hline Headache & $5(11.4 \%)$ & $11(19.6 \%)$ & $16(16 \%)$ \\
\hline Vomiting & $6(13.6 \%)$ & $13(23.2 \%)$ & $19(19 \%)$ \\
\hline
\end{tabular}




\begin{tabular}{|l|c|c|c|}
\hline Fever & $21(47.7 \%)$ & $28(50 \%)$ & $49(49 \%)$ \\
\hline Childhood ear disease & $21(47.7 \%)$ & $15(26.8 \%)$ & $36(36 \%)$ \\
\hline Type of perforation & $\begin{array}{c}\text { Active } \\
\text { mucosal } \\
\text { ( Total : 44 })\end{array}$ & $\begin{array}{c}\text { Active } \\
\text { squamosal } \\
\text { ( Total : 56) }\end{array}$ & Total( 100 ) \\
\hline Central & $12(27.3 \%)$ & - & $12(12 \%)$ \\
\hline Sub - total & $29(65.9 \%)$ & - & $29(29 \%)$ \\
\hline Total & $3(6.8 \%)$ & - & $3(3 \%)$ \\
\hline Marginal & - & $26(46.4 \%)$ & $26(26 \%)$ \\
\hline Attic & - & $30(53.6 \%)$ & $30(30 \%)$ \\
\hline
\end{tabular}

In the present study $100 \%$ of Complicated COM cases presented with Otorrhea as the main complaint whereas $88 \%$ of cases presented with decreased hearing, $76 \%$ presented with Otalgia and $49 \%$ presented with fever. $36 \%$ of cases had childhood ear disease. 53.6\% of Active Squamosal $\mathrm{COM}$ cases presented with Attic perforation whereas $46.4 \%$ of cases presented with Marginal perforation. $65.9 \%$ of Active Mucosal COM cases had Sub - Total perforation.

Table 3: Distribution of study population according to Pathology

\begin{tabular}{|c|c|c|c|}
\hline Site of complication & $\begin{array}{l}\text { Active mucosal } \\
(\text { Total }: 44)\end{array}$ & $\begin{array}{c}\text { Active } \\
\text { squamosal } \\
(\text { Total : 56) }\end{array}$ & Total (100) \\
\hline Intratemporal & $39(88.6 \%)$ & $45(80.4 \%)$ & $84(84 \%)$ \\
\hline Intracranial & $5(11.4 \%)$ & $11(19.6 \%)$ & $16(16 \%)$ \\
\hline Intratemporal complications & $\begin{array}{l}\text { Active mucosal } \\
(\text { Total : } 39)\end{array}$ & $\begin{array}{c}\text { Active } \\
\text { squamosal } \\
(\text { Total : 45) }\end{array}$ & Total ( 84 ) \\
\hline Acute mastoiditis & $19(48.7 \%)$ & $18(40 \%)$ & $37(44 \%)$ \\
\hline $\begin{array}{l}\text { Acute mastoiditis + Post auricular } \\
\text { abscess }\end{array}$ & $6(15.3 \%)$ & $6(13.4 \%)$ & $12(14.3 \%)$ \\
\hline $\begin{array}{l}\text { Acute mastoiditis + Post auricular } \\
\text { abscess }+ \text { Zygomatic abscess }\end{array}$ & $1(2.6 \%)$ & $2(4.4 \%)$ & $3(3.6 \%)$ \\
\hline $\begin{array}{l}\text { Acute mastoiditis }+ \text { Bezold's } \\
\text { abscess }\end{array}$ & $1(2.6 \%)$ & - & $1(1.2 \%)$ \\
\hline $\begin{array}{l}\text { Acute mastoiditis + Post auricular } \\
\text { abscess + Luc's abscess }\end{array}$ & $1(2.6 \%)$ & $3(6.7 \%)$ & $4(4.7 \%)$ \\
\hline $\begin{array}{l}\text { Chronic mastoiditis }+ \text { Post } \\
\text { auricular fistula }\end{array}$ & - & $1(2.2 \%)$ & $1(1.2 \%)$ \\
\hline Facial paralysis & $10(25.6 \%)$ & $12(26.7 \%)$ & $22(26.2 \%)$ \\
\hline Acute suppurative labyrinthitis & $1(2.6 \%)$ & $2(4.4 \%)$ & $3(3.6 \%)$ \\
\hline Labyrinthine fistula & - & $1(2.2 \%)$ & $1(1.2 \%)$ \\
\hline Petrositis & - & - & - \\
\hline Intracranial complications & $\begin{array}{l}\text { Active mucosal } \\
(\text { Total : } 5 \text { ) }\end{array}$ & $\begin{array}{c}\text { Active } \\
\text { squamosal } \\
\text { ( Total : 11) }\end{array}$ & Total ( 16 ) \\
\hline Meningitis & $2(40 \%)$ & $3(27.3 \%)$ & $5(31.25 \%)$ \\
\hline Brain abscess & $3(60 \%)$ & $\begin{array}{c}7(63.6 \%) \\
\text { ( Temporal } \\
\text { lobe abscess } \\
-6, \\
\text { Cerebellar } \\
\text { abscess }-1)\end{array}$ & $10(62.5 \%)$ \\
\hline Lateral sinus thrombophlebitis & - & $1(9.1 \%)$ & $1(6.25 \%)$ \\
\hline Middle ear pathology & $\begin{array}{l}\text { Active mucosal } \\
(\text { Total }: 44)\end{array}$ & $\begin{array}{c}\text { Active } \\
\text { squamosal } \\
\text { ( Total : 56) } \\
\end{array}$ & Total (100) \\
\hline Granulation & $20(45.5 \%)$ & $20(35.7 \%)$ & $40(40 \%)$ \\
\hline Cholesteatoma sac & - & $56(100 \%)$ & $56(56 \%)$ \\
\hline Polyp & $21(47.7 \%)$ & $16(28.6 \%)$ & $37(37 \%)$ \\
\hline Mucosal edema & $3(6.8 \%)$ & - & $3(3 \%)$ \\
\hline
\end{tabular}


Figure 1: Distribution of study population according to Intratemporal Complications

\section{INTRATEMPORAL COMPLICATIONS}

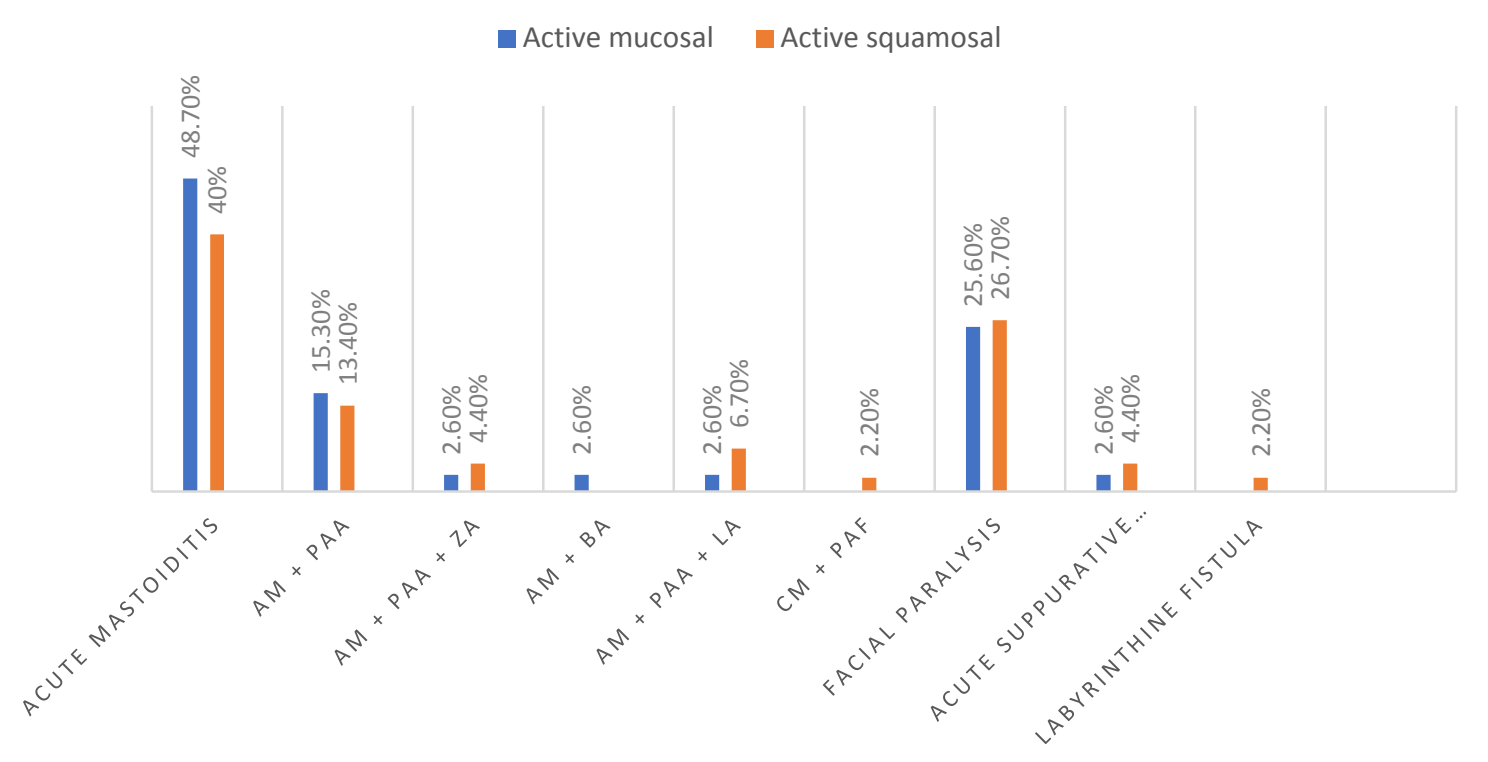

Figure 2: Distribution of study population according to Intracranial Complications

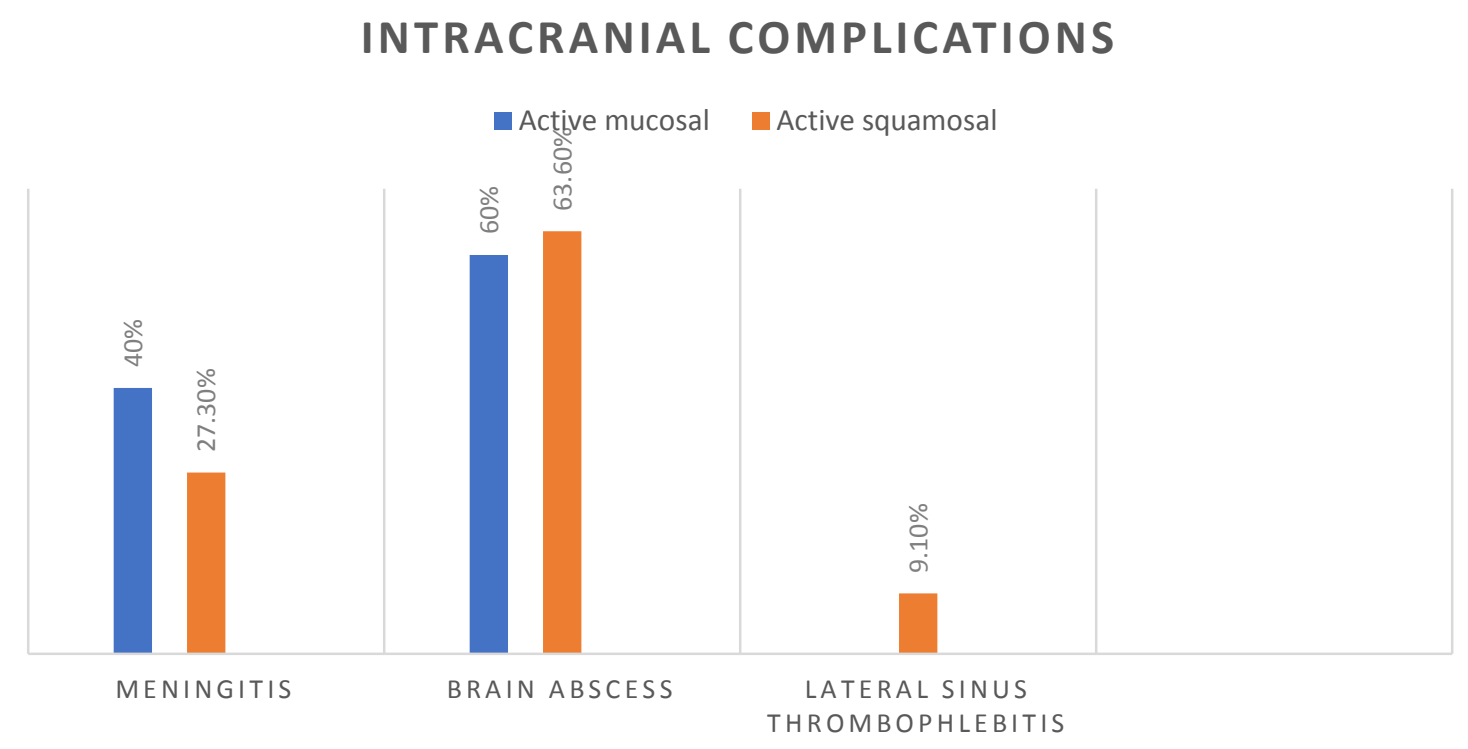

In the present study, the maximum incidence was of Intratemporal complications (84\%) whereas Intracranial complications accounted for $16 \%$ of cases. In Active Mucosal COM, the incidence of Intratemporal complications was $88.6 \%$ and that of Intracranial complications was $11.4 \%$. In Active Squamosal COM, the incidence of Intratemporal complications was $80.4 \%$ and that of Intracranial complications was $19.6 \%$. Acute Mastoiditis accounted for highest incidence of Intratemporal Complications (44\%) of which $48.7 \%$ of cases were noted in Active Mucosal
COM and $40 \%$ of cases were noted in Active Squamosal COM. Facial paralysis accounted for second highest incidence of Intratemporal Complications $(26.2 \%)$ of which $25.6 \%$ of cases were noted in Active Mucosal COM and $26.7 \%$ of cases were noted in Active Squamosal COM. Brain abscess accounted for highest incidence of Intracranial Complications $(62.5 \%)$ of which $60 \%$ of cases were noted in Active Mucosal COM and $63.6 \%$ cases were noted in Active Squamosal COM. 
Table 4: Distribution of study population according to Organism cultured from discharge

\begin{tabular}{|l|c|c|c|}
\hline Organism isolated on culture & $\begin{array}{c}\text { Active mucosal } \\
(\text { Total : 44) }\end{array}$ & $\begin{array}{c}\text { Active squamosal } \\
\text { ( Total : 56) }\end{array}$ & Total ( 100 ) \\
\hline No organism isolated & $12(27.3 \%)$ & $34(60.7 \%)$ & $46(46 \%)$ \\
\hline Streptococcus pneumonia & $10(22.7 \%)$ & $5(8.9 \%)$ & $15(15 \%)$ \\
\hline Pseudomonas & $17(38.7 \%)$ & $16(28.6 \%)$ & $33(33 \%)$ \\
\hline E. Coli & $2(4.5 \%)$ & - & $2(2 \%)$ \\
\hline Klebsiella sp. & $1(2.3 \%)$ & $1(1.8 \%)$ & $2(2 \%)$ \\
\hline Proteus sp. & $2(4.5 \%)$ & - & $2(2 \%)$ \\
\hline
\end{tabular}

In $46 \%$ of cases no organism was isolated on culture (Active Mucosal COM - 27.3\%, Active Squamosal COM $-60.7 \%$ ). In $33 \%$ of cases

Pseudomonas was isolated on culture (Active Mucosal COM - 38.7\%, Active Squamosal COM $-28.6 \%)$.

Table 5: Distribution of study population according to Management and Outcome

\begin{tabular}{|c|c|c|c|}
\hline Management & $\begin{array}{l}\text { Active mucosal } \\
\text { ( Total : } 44 \text { ) }\end{array}$ & $\begin{array}{l}\text { Active squamosal } \\
\quad(\text { Total : } 56)\end{array}$ & Total ( 100 ) \\
\hline $\begin{array}{l}\text { IV Antibiotics depending upon culture } \\
\text { or } 3^{\text {rd }} \text { generation cephalosporins }\end{array}$ & $44(100 \%)$ & $56(100 \%)$ & $100(100 \%)$ \\
\hline Steroids( IV\& Oral ) & $5(11.4 \%)$ & $10(17.9 \%)$ & $15(15 \%)$ \\
\hline Labyrinthine sedatives & $1(2.3 \%)$ & $2(3.6 \%)$ & $3(3 \%)$ \\
\hline Canal wall up mastoidectomy & $25(56.8 \%)$ & - & $25(25 \%)$ \\
\hline $\begin{array}{l}\text { Surgical drainage \& Canal wall up } \\
\text { mastoidectomy }\end{array}$ & $8(18.2 \%)$ & - & $8(8 \%)$ \\
\hline $\begin{array}{l}\text { Canal wall up mastoidectomy with } \\
\text { facial nerve decompression }\end{array}$ & $10(22.7 \%)$ & - & $10(10 \%)$ \\
\hline Canal wall down mastoidectomy & - & $31(55.4 \%)$ & $31(31 \%)$ \\
\hline $\begin{array}{l}\text { Surgical drainage \& Canal wall down } \\
\text { mastoidectomy }\end{array}$ & - & $12(21.4 \%)$ & $12(12 \%)$ \\
\hline $\begin{array}{l}\text { Canal wall down mastoidectomy with } \\
\text { facial nerve decompression }\end{array}$ & - & $12(21.4 \%)$ & $12(12 \%)$ \\
\hline $\begin{array}{l}\text { Canal wall down mastoidectomy with } \\
\text { sealing of fistula }\end{array}$ & - & $1(1.8 \%)$ & $1(1 \%)$ \\
\hline $\begin{array}{l}\text { Canal wall down mastoidectomy with } \\
\text { evacuation of clot from sigmoid sinus }\end{array}$ & - & $1(1.8 \%)$ & $1(1 \%)$ \\
\hline Craniotomy and drainage of abscess & $3(6.8 \%)$ & $7(12.5 \%)$ & $10(10 \%)$ \\
\hline Outcome & $\begin{array}{l}\text { Active mucosal } \\
(\text { Total }: 44)\end{array}$ & $\begin{array}{l}\text { Active squamosal } \\
(\text { Total : } 56)\end{array}$ & Total ( 100$)$ \\
\hline Completely healed \& dry ear & $26(59.1 \%)$ & $35(62.5 \%)$ & $61(61 \%)$ \\
\hline Persistent discharge & $18(40.9 \%)$ & $21(37.5 \%)$ & $39(39 \%)$ \\
\hline
\end{tabular}

In the present study $100 \%$ of cases were treated with IV antibiotics. Active Mucosal Complicated COM cases were managed with Canal Wall Up Mastoidectomy whereas Active Squamosal Complicated COM cases were managed with Canal Wall Down Mastoidectomy. Brain abscess cases were dealt with Neurosurgical intervention before subjecting to Canal Wall Down Mastoidectomy. $61 \%$ of Complicated COM cases had better outcome in the form of dry ear whereas in $39 \%$ of cases there was persistent discharge.

\section{Discussion}

In the present study, $1930 \mathrm{COM}$ cases presented to the Tertiary Care Hospital of which 100 cases had Complications, the Incidence of complications accounting to $5.2 \%$. Of the 100 Complicated $\mathrm{COM}$ cases $44 \%$ cases were of Active Mucosal COM whereas $56 \%$ cases were of Active Squamosal COM. This suggests that the highest incidence of complications were noted in Active Squamosal COM. The age distribution in present study suggests that complications are highest in 31-60 years of age group. In Active Mucosal COM cases Complications were highest in young patients $(11-30 \mathrm{yrs}-38.6 \%)$ whereas in Active 
Squamosal COM cases Complications were highest in middle aged patients $(31-60 \mathrm{yrs}-$ $71.4 \%$ ). This is in accordance to the Yorgancilar et al study according to which Complications of $\mathrm{COM}$ are common in young age and middle aged group. ${ }^{6}$

The gender distribution in present study suggests highest incidence of complications in male gender $(60 \%)$. This is in accordance to the Mustafa et $\mathrm{al}^{7}$ according to which highest incidence of complications is noted in males for reasons unknown.

The majority of patients belonged to Rural area (74\%) and Low Socio - Economic status (78\%). This is in accordance to Pawar et al study ${ }^{8}$ and Sengupta et al study. ${ }^{9}$

The most common complaint of Complicated COM cases were Otorrhea, decreased hearing, Otalgia and fever. This is in accordance to Kangsanarak $\mathrm{J}$ et $\mathrm{al}^{10}$ study according to which most common presenting complaint accounts to Otorrhea and fever. 53.6\% of Active Squamosal COM cases presented with Attic perforation whereas $46.4 \%$ of cases presented with Marginal perforation. $65.9 \%$ of Active Mucosal COM cases had Sub - Total perforation.

Of the 100 Complicated COM cases, Intratemporal Complications accounted to $84 \%$ (Active Mucosal COM - 88.6\%, Active Squamosal COM - 80.4\%) whereas Intracranial Complications accounted to $16 \%$ (Active Mucosal COM - $11.4 \%$, Active Squamosal COM 19.6\%). Hence Intratemporal Complications accounted for highest incidence of Complications both in Active Mucosal and Active Squamosal COM cases. This is in accordance to Kangsanarak $\mathrm{J}$ et $\mathrm{al}^{10}$ and Mustafa et al study ${ }^{7}$ according to which Intratemporal Complications are of highest incidence. Acute Mastoiditis (44\%) followed by Facial Paralysis (26.2\%) accounted for highest incidence of Intratemporal Complications. This is in accordance to Pawar et $\mathrm{al}^{8}$ study according to which Acute Mastoiditis is the most common Intratemporal Complication. Whereas Brain abscess $(62.5 \%)$ accounted for highest incidence of Intracranial Complications. This is in accordance to Memon et al study. ${ }^{11}$

No organism was cultured in majority of cases $(46 \%)$. This is in accordance to Sennaroglu et $\mathrm{al}^{12}$ study. Pseudomonas $(33 \%)$ was the organism which was isolated in maximum number of Complicated COM cases.

Majority of Complicated cases of Active Mucosal COM were successfully managed with Canal Wall Up Mastoidectomy (43 cases) whereas majority of Complicated cases of Active Squamosal COM were managed with Canal Wall Down Mastoidectomy (56 cases ). The intra - operative findings in majority of cases was Cholesteatoma (56\%) followed by Granulations (40\%) in present study. This is in accordance to Osma et al study. ${ }^{3}$ The intra - operative finding in Facial Nerve Paralysis suggested the involvement of Fallopian Canal via Granulation tissue and Cholesteatoma. This is in accordance to Yorgancilar et al study. ${ }^{6}$ The tympanic segment was most commonly involved segment. This is in accordance to Woong et $\mathrm{al}^{13}$ study. Brain abscess cases were referred to Neurosurgical Department for intervention before performing Mastoidectomy. $61 \%$ of Complicated COM cases had better outcome in the form of dry ear whereas in $39 \%$ of cases there was persistent discharge.

\section{Conclusion}

There is a decline in the incidence of Complications in COM cases due to advent of antibiotics and vaccination. However when Complications do occur they pose a challenge to Otolaryngologist. Clinical features and Radiology help in pointing towards the diagnosis and ordering further investigations for final diagnosis. Complications require prompt management to prevent mortality and morbidity associated with it.

\section{References}

1. Ologe FE, Nwawolo CC. Prevalence of chronic suppurative otitis media among school children in a rural community in Nigeria. Nig Postgrad Med J. 2002;9:63-6. 
2. Acuin J. Chronic suppurative otitis mediaburden of illness and management options. Geneva: World Health Organization, 2004

3. Osma U, Cureoglu S, Hosoglu S (2000) The complications of chronic otitis media: report of 93 cases. J LaryngolOtol 114:97100

4. Dubey SP, Larawin V (2007) Complications of chronic suppurative otitis media and their management. Laryngoscope 117:264-267 2.

5. Dubey SP, Larawin V, Molumi CP (2010) Intracranial spread of chronic middle ear suppuration. Am J Otolaryngol 31(2):7377

6. E.Yorgancilar, M.Yildirim, R.Gun, S.Bakir, R.Tekin, C.Gocmez, F.Meric, I.Topcu : Complications of chronic suppurative otitis media: a retrospective review. Eur Arch Otorhinolaryngol (2013) 270:69-76

7. Mustafa A, Heta A, Kastrati B, DreshajSh (2008) Complications of chronic otitis media with cholesteatoma during a 10-year period in Kosovo. Eur Arch Otorhinolaryngol 265(12):1477-1482

8. Swapnil R. Pawar, Yogesh Shukla : A clinical study on complications of chronic suppurative otitis media and level of awareness in patients admitted at tertiary care hospital in central India. International Journal of Community Medicine and Public Health Pawar SR et al. Int J Community Med Public Health. 2015 Aug;2(3):223-227

9. Sengupta A, Anwar T, Ghosh D, Basak B. A study of surgical management of chronic suppurative otitis media with cholesteatoma and its outcome. Indian $\mathrm{J}$ Otolaryngol Head Neck Surg. 2010;62(2):171-76.
10. Kangsanarak J, Fooanant S, Ruckphaopunt K, Navacharoen N, Teotrakul S (1993) Extracranial and intracranial complications of suppurative otitis media: report of 102 cases. J LaryngolOtol 107:999-1004

11. Memon MA, Matiullah S, Ahmed Z, Marafani MS. Frequency of un-safe chronic suppurative Otitis in patients with discharging ear. JLUMHS. 2008;102- 5.

12. Sennaroglu L, Sozeri B (2000) Otogenic brain abscess: review of 41 cases. Otolaryngol Head Neck Surg 123:751-755

13. JinWoong Choi, Yong-Ho Park : Facial Nerve Paralysis in Patients With Chronic Ear Infections: Surgical Outcomes and Radiologic Analysis. Clinical and Experimental Otorhinolaryngology 2015; 8(3): 218-223. 